\title{
Effects of emersion and re-immersion on physiological and immunological variables in creel-caught and trawled Norway lobster Nephrops norvegicus
}

\author{
C. J. Bernasconi, R. F. Uglow* \\ Department of Biological Sciences, University of Hull, Hull HU6 7RX, UK
}

\begin{abstract}
Immune defence in creel-caught and trawled Nephrops norvegicus was investigated to assess a possible relationship between phenoloxidase (PO) activation and the total haemocyte count (THC). Capture, capture method and emersion evoked physiological and immunological responses that may have implications for the ability of $N$. norvegicus to survive the effects of such stressors. Haemolymph THC was always negatively related to PO activity in the trawled samples, suggesting a decreased level of the plasma serine proteinase inhibitors which reportedly regulate the ProPO system (Le Moullac et al. 1998; Fish shellfish Immunol 8:621-629). In contrast, creel-caught samples showed increased levels of both PO and THC (cf. control N. norvegicus), after a $12 \mathrm{~h}$ emersion period. Trawling and emersion evoked progressive and significant increases $(p<0.05)$ in the mean levels of haemolymph L-lactate, glucose and total ammonia. The evidence of overt activity and measured haemolymph parameters suggest that creel fishing yields $N$. norvegicus that are more likely to survive post-harvest treatments than those that are trawled.
\end{abstract}

KEY WORDS: Nephrops norvegicus $\cdot$ Immune defence $\cdot$ Catching methods $\cdot$ Emersion $\cdot$ Immersion Intrinsic quality maintenance

Resale or republication not permitted without written consent of the publisher

\section{INTRODUCTION}

Crustaceans lack immunoglobins, but they have phagocytic haemocytes that aid wound closure and clotting (Bauchau 1981) and a humoral system, both of whose activities are coordinated by a cell-based phenoloxidase (PO) enzyme cascade system. In crustaceans, mechanical injuries or the presence of foreign objects result in melanin deposition around the damaged tissue or intruding object. This acts as a physical shield against an intruder, preventing or retarding its growth but more importantly, resulting in the formation of highly reactive and toxic quinine intermediates.

'Non-self' recognition is via the haemocyte-borne prophenoloxidase (ProPO) activating system (Söderhäll 1982). The active enzyme PO (o-diphenol-oxygen oxidoreductase) is produced during activation of the immune system by microbial cell wall components. It is proposed to be a self-recognition system because ProPO conversion to PO can be induced by minuscule amounts of the stimulating molecules (Söderhäll \& Cerenius 1998, Yildiz \& Atar 2002). Morphologically different haemocyte types like hyalinocytes, semigranulocytes and granulocytes (Bauchau 1981, Söderhäll \& Smith 1983) are attributed with specific functional activities (e.g. ProPO activation, Cerenius \& Söderhäll 1995). Phagocytosis, coagulation, release of agglutinins and synthesis of melanin may also be evoked by abnormal environmental stressors (Jussila et al. 1997).

Current models of the crustacean PO system suggest that ProPO is released as a zymogen from the semigranular and granular cells into the plasma where it is activated by a serine proteinase. Söderhäll \& Smith (1983) first isolated ProPO in the granulocytes, but found no ProPO activity in the plasma. In contrast, Per- 
azzolo \& Barraco (1997) found plasma ProPO activity to be $<10 \%$ of total activity in Penaeus paulensis plasma, while Hernandez-Lopez et al. (1996) found $83 \%$ of the PO activity to be located in plasma in the spiny lobster Panulirus interruptus.

The commercial transportation of live crustaceans is now common in the highly specialised live seafood trade that demands quality products to be delivered consistently and cost-effectively. The transportation phase may be of short distance or duration $(10 \mathrm{~s}$ of $\mathrm{km}$ or hours, e.g. to home port) or long (days or 1000s of $\mathrm{km}$, e.g. from the UK to Spain or Russia). Economic considerations dictate exclusion of seawater and long emersion times for longer journeys. In many instances, the delivered animals are sold rapidly as 'fresh' products, but there is increasing demand for animals that could be husbanded following delivery so that the sale period can be extended to match consumer demand. Unfortunately for Nephrops norvegicus, the practices and methods used along such marketing chains from capture to final sale-are not ideally suited to survival or general quality maintenance, thus tending to jeopardise commercial goals. Frequently encountered stressors include extended periods of emersion, desiccation, rapid temperature and/or salinity changes and supranormal internal and/or external ammonia levels. In addition, physical damage particularly to limbs, occurs frequently as a consequence of catching and postharvest handling, and this results in debilitating blood loss (Uglow et al. 1986).

The present study aimed to use total haemocyte count (THC) and PO as haematological indicators of environmentally induced immune defence in a commercially fished marine decapod crustacean, (Smith \& Johnston 1992, Hauton et al. 1995, Jussila et al. 1997), so as to provide additional information on changes evoked by events associated with capture and capture methods, including emersion. Such information would supplement the quantitative data on other parameters (e.g. haemolymph lactate, glucose, and ammonia levels) that are anticipated to change with stressor intensity. Commercially, Nephrops norvegicus are often required to be delivered alive, in good condition, and also with high expectancy of survival on being returned to seawater holding systems. As some postharvest emersion is inevitable, particular attention has been paid to determining the modifying effects of emersion duration. Because it is generally assumed that capture methods differ in the severity of their imposed stress, these studies were made using both trawled and creel-caught $N$. norvegicus. There is now a global dimension to the trade in live crustaceans and a better appreciation of the physiological effects of capture methods and emersion duration is required to facilitate more efficient, cost-effective distribution sys- tems and provide better insights into the responses of these animals to such stressors. Behavioural or physiological strategies that serve to increase tolerance to low oxygen events will have considerable adaptive value for the species and may offer an avenue to explore new ways of distributing these commercially valuable animals.

\section{MATERIALS AND METHODS}

Creel-caught Nephrops norvegicus were obtained from the NW coast of Scotland and long-trawled $N$. norvegicus from the NE coast of England. The creelcaught animals were brought from the holding ponds of a Scottish dealer to the laboratory, and the longtrawled animals were from the final trawl of the day. All N. norvegicus were brought to the laboratory in polystyrene boxes containing an ice gel pack. At Hull University, they were maintained in plastic, opaque tanks (1.5 m inner diameter, 500 l) supplied with biologically filtered, recirculating, aerated seawater (salinity $=35 \pm 1$; temperature $=5^{\circ} \mathrm{C} ;$ a $12: 12 \mathrm{~h}$ light:dark photoperiod and $<100 \mu \mathrm{mol} \mathrm{NH}_{4} \mathrm{l}^{-1}$ ). Prior to being used for experiments, all $N$. norvegicus were held for $24 \mathrm{~h}$ to allow temperature acclimation and recovery from transportation and handling stresses.

Groups of 18 adult Nephrops norvegicus from each capture method (mean weight $=56.40 \pm 1.01 \mathrm{~g}$ for creel-caught and $50.35 \pm 1.65 \mathrm{~g}$ for trawl-caught samples) were emersed for $0 \mathrm{~h}$ (control) and $12 \mathrm{~h}$. No mortalities occurred in any group. Experimental emersion involved careful removal from the water and packing in a polystyrene box with seawater-dampened newspaper and a large gel ice pack. Each box was stored for the appropriate duration in a temperature-controlled room $\left(5 \pm 1^{\circ} \mathrm{C}\right)$. At the end of the $12 \mathrm{~h}$ emersion period, each box was unpacked and 6 lobsters were reimmersed for $2 \mathrm{~h}$ into individual, acid-washed tanks each holding 11 seawater [salinity $=35 ;<10 \mu$ mol total ammonia (TA) $\mathrm{l}^{-1}$ ]. Haemolymph samples were collected from separate groups $(\mathrm{n}=6)$ prior to emersion (control), after $12 \mathrm{~h}$ emersion, and at the end of the $2 \mathrm{~h}$ re-immersion period. Emersion and re-immersion durations are based on those that occur in many consignments of Nephrops made daily in the UK.

Haemolymph samples $(1.5 \mathrm{ml})$ were collected using a $2 \mathrm{ml}$ syringe (Hamilton), the needle (23 gauge) of which was inserted either through the arthrodial membrane at the base of the 5th pereiopod, or beneath the cephalothorax and into the pericardium. Each haemolymph sample was divided into 3 aliquots and kept in labelled microcentrifuge tubes kept on ice.

Haemolymph L-lactate was measured using Trinity Biotech diagnostic kit no. 735-10 and haemolymph 
glucose using Sigma diagnostic kit no. 510-A. Ammonia concentrations were measured using a flow-injection gas diffusion system (Hunter \& Uglow 1993). PO activity was determined by adapting the methods of Söderhäll (1981), Smith \& Söderhäll (1983), Söderhäll \& Smith (1983), and Jackson et al. (1993). For this assay, all glassware and pipette tips were washed with liposol to remove any trace oxidants before being rinsed twice in deionised water and once in Milli-Q water. These were then sterilised by autoclaving at $120^{\circ} \mathrm{C}$ for $20 \mathrm{~min}$ to remove any bacterial films. All buffers and reagents were made up with Milli-Q water as required (Hauton et al. 1995).

Haemolymph samples $(0.6 \mathrm{ml}$ each) required for the ProPO studies were extracted using a $2 \mathrm{ml}$ syringe with a 23 gauge needle (Hamilton), containing $0.4 \mathrm{ml}$ of icecold citrate EDTA buffer ( $\mathrm{pH}=4.6$ ) (Söderhäll \& Smith 1983) as an anticoagulant. Each sample was centrifuged at $450 \mathrm{rpm}$ for $15 \mathrm{~min}$ and the pellet of haemocytes was washed twice, without re-suspension, with $2 \mathrm{ml}$ of ice-cold $0.01 \mathrm{M}$ sodium cacodylate citrate buffer at pH 7 (Jackson et al. 1993). Samples were then rapidly frozen by immersion in liquid nitrogen, in $2 \mathrm{ml}$ of $0.01 \mathrm{M}$ sodium cacodylate buffer at $\mathrm{pH} 7$, and stored frozen until analysis. Prior to analysis, each sample was slowly defrosted and homogenised using a glass piston homogeniser on ice at a constant room temperature of $5^{\circ} \mathrm{C}$. Each sample was then centrifuged at $900 \mathrm{rpm}$ at $3^{\circ} \mathrm{C}$ for a further $25 \mathrm{~min}$ to remove cell debris and the supernatant, designated HLS was then assayed for phenoloxidase activity.

PO occurs as an inactive zymogen within the granulocytes of crustaceans and thus requires activating by an elicitor, in this case trypsin. Four hundred $\mu \mathrm{l}$ of HLS were incubated at $15^{\circ} \mathrm{C}$ with $400 \mu \mathrm{l}$ of $0.1 \%$ trypsin (0.5 Anson units $\mathrm{g}^{-1}$ from beef pancreas) in cacodylate buffer. After $1 \mathrm{~h}, 400 \mu \mathrm{l}$ of dihydroxyphenylalanine (Ldopa, $4 \mathrm{~g} 1^{-1}$ in Milli-Q water) was added to the activated HLS and the change in the absorbance of the sample was measured over the first $5 \mathrm{~min}$. A control was prepared for each individual sample to correct for any background oxidation of the L-dopa by the cacodylate buffer or the inactive HLS. The controls consisted of $400 \mu$ l each of HLS, cacodylate buffer (to replace the trypsin) and Ldopa, and similarly treated as the samples. Enzyme activity was expressed in units where 1 unit represented an increase in absorbance of the sample of $0.001 \mathrm{~min}^{-1}$ at $490 \mathrm{~nm}$. All measurements were made on a Cecil CE 292 Digital Ultraviolet Spectrophotometer.

THCs for individual animals were estimated with a haemocytometer under $100 \times$ magnification, using $0.15 \mathrm{ml}$ of haemolymph drawn from the pericardial sinus with a $2 \mathrm{ml}$ syringe. The haemolymph was transferred to a $0.6 \mathrm{ml}$ microcentrifuge tube containing $0.15 \mathrm{ml}$ of ice-cooled anticoagulant for THC. The sam- ple was immediately placed on ice. From this diluted sample, $10 \mu \mathrm{l}$ were taken and transferred into a Neubauer haemocytometer (Hausser Scientific). Two replicates each of four $0.004 \mathrm{~mm}^{3}$ sections were counted and the mean was taken as the haemocytometer count. THC (cells ml-1) was calculated as:

$$
\mathrm{THC}=\mathrm{HC} / 8 \times \mathrm{CF} / 0.004 \times \mathrm{DF}
$$

where $\mathrm{HC}$ is the haemocytometer count, $\mathrm{CF}$ is the conversion factor (1000) for changing $\mathrm{mm}^{3}$ to $\mathrm{ml}$, and DF is the dilution factor (2). THC analysis was completed within $2 \mathrm{~h}$; cell lysis and haemolymph coagulation occurred after $3 \mathrm{~h}$.

During this investigation, the plasma was discarded during the preparation of the haemocyte lysate supernatant (HLS). As a consequence, the levels of PO activity given here indicate the total amount of ProPO being stored in the granulocytes only and do not indicate any of the activated PO that may have been present in the plasma. Preliminary tests supported the findings of Söderhäll \& Smith (1983) of undetectable ProPO activity in the plasma of Nephrops norvegicus.

All data are represented as means $\pm \mathrm{SE}$. The number of lobsters measured (n) is given in parenthesis. Statistical differences between sample means were tested for significance using $t$-test or ANOVA and Levene's test for homogeneity of variances. Multiple range tests were used to identify groups that were significantly different at $\mathrm{p}<0.05$. For data with non-normal distribution, the less stringent, non-parametric, Mann-Whitney $U$-test was adopted.

\section{RESULTS}

No mortalities occurred during these investigations, but the trawled samples had noticeably reduced movements compared with those that were creel-caught. The haemolymph of the trawled group also had significantly higher levels of some quantifiable variables that are generally interpreted as being indicative of the impact of stressors (cf. the creeled group) (Table 1). Only haemolymph glucose levels were the same in the 2 groups.

The $12 \mathrm{~h}$ emersion period evoked increases in PO activity that were significant $(p<0.05)$ in the trawled group only (Fig. 1), and re-immersion did not affect the trawled group which maintained a significantly higher HLS PO activity than its control group ( $p<0.05)$.

The effect of the $12 \mathrm{~h}$ emersion period on THCs was a significant increase in the creeled group and a significant decrease in the trawled group ( $p<0.05$ in each case). The $2 \mathrm{~h}$ re-immersion period had no significant effect on the THCs of either group ( $p>0.05$ in both cases) (Fig. 2). 
Table 1. Concentrations (mean $\pm \mathrm{SE}$ ) of some haemolymph constituents in creeled and trawled Nephrops norvegicus (n = 6) before and after emersion and re-immersion (re-imm). TA: total ammonia; PO: phenoloxidase; abs: absorbance; THC: total haemocyte count

\begin{tabular}{|c|c|c|c|c|c|c|}
\hline & & 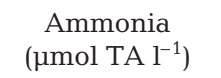 & $\begin{array}{l}\text { Glucose } \\
\left(\mathrm{mmol} \mathrm{l}^{-1}\right)\end{array}$ & $\begin{array}{l}\text { Lactate } \\
\left(\mathrm{mmol} \mathrm{l}^{-1}\right)\end{array}$ & $\begin{array}{c}\text { PO activity } \\
\left(\text { abs } \min ^{-1} \mathrm{ml}^{-1}\right)\end{array}$ & $\begin{array}{c}\text { THC } \\
\left(10^{6} \text { cells ml }^{-1}\right)\end{array}$ \\
\hline $0 \mathrm{~h}$ & Creeled & $207.13 \pm 63.33$ & $0.46 \pm 0.07$ & $0.06 \pm 0.02$ & $0.14 \pm 0.02$ & $5.9 \pm 0.93$ \\
\hline $12 \mathrm{~h}$ & Emersed & $691.79 \pm 83.37$ & $0.37 \pm 0.11$ & $0.51 \pm 0.26$ & $0.20 \pm 0.07$ & $11.0 \pm 2.07$ \\
\hline$+2 \mathrm{~h}$ & Re-imm & $388.30 \pm 89.75$ & $0.20 \pm 0.06$ & $0.36 \pm 0.24$ & $0.14 \pm 0.03$ & $10.0 \pm 1.37$ \\
\hline $0 \mathrm{~h}$ & Trawled & $931.35 \pm 122.18$ & $0.55 \pm 0.17$ & $3.20 \pm 1.80$ & $0.35 \pm 0.12$ & $17.0 \pm 1.25$ \\
\hline $12 \mathrm{~h}$ & Emersed & $937.31 \pm 136.77$ & $0.79 \pm 0.18$ & $17.88 \pm 3.62$ & $0.70 \pm 0.15$ & $1.1 \pm 0.16$ \\
\hline$+2 \mathrm{~h}$ & Re-imm & $200.31 \pm 37.06$ & $1.63 \pm 0.29$ & $17.93 \pm 2.47$ & $0.70 \pm 0.21$ & $0.7 \pm 0.07$ \\
\hline
\end{tabular}

In the creeled group, circulating glucose levels did not change significantly during emersion or re-immersion and this contrasted with the progressive hyperglycaemia that occurred in the trawled Nephrops norvegicus. The increase in the trawled group was not significant after $12 \mathrm{~h}$ emersion but was significantly higher $(p<0.05)$ than that of the control by the end of the $2 \mathrm{~h}$ re-immersion period (Fig. 3).

Emersion resulted in significant increases $(p<0.05)$ in the mean concentration of haemolymph L-lactate in both groups (Fig. 4, Table 1). That in the creeled group, however, remained significantly lower than in the trawled group $\left(0.51 \pm 0.26\right.$ and $17.88 \pm 3.62 \mathrm{mmol} \mathrm{l}^{-1}$, respectively). The $2 \mathrm{~h}$ re-immersion period evoked further increases in both groups but this only reached statistical significance $(p<0.05)$ in the trawled group.

After $12 \mathrm{~h}$ emersion, the blood ammonia level in the creeled group was significantly higher $(\mathrm{p}<0.05)$ than that of its control group (Fig. 5, Table 1). However, this was still significantly lower than the level in the corresponding trawled group, which showed no significant effects attributable to emersion $(p>0.05)$. Blood

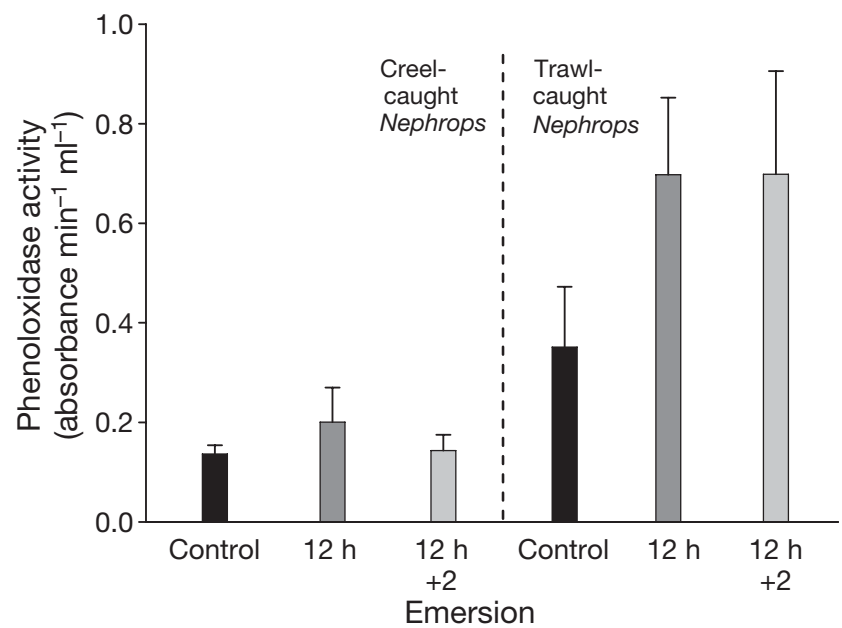

Fig. 1. Nephrops norvegicus. Haemolymph phenoloxidase (PO) activity (mean $+\mathrm{SE}$ ) in creeled and trawled specimens after $0 \mathrm{~h}$ (control), $12 \mathrm{~h}$ emersion, and $12 \mathrm{~h}$ emersion and $2 \mathrm{~h}$ re-immersion $(\mathrm{n}=6)$ ammonia levels decreased significantly in both groups during the $2 \mathrm{~h}$ re-immersion period ( $\mathrm{p}<0.05$ in both cases) but this change was particularly prominent in the trawled group $(\mathrm{p}<0.05)$, which had a final value significantly less than that of the creeled group and its own control group ( $p<0.05$ in each case). The creeled group had a final blood ammonia level that was significantly higher than that of its own control group.

\section{DISCUSSION}

These findings indicate that Nephrops norvegicus have different behavioural strategies and physiological tolerances, and thus show different responses to altered environmental variables such as emersion. Such environmental changes alter the immune status of crustaceans (Perazzolo \& Barracco 1997, Le Moullac et al. 1998, Söderhäll et al. 2003). Here we have shown that commercial fishing methods for decapod crustaceans (e.g. creeling and trawling) are also stressful and result in a diminished immune vigour as measured

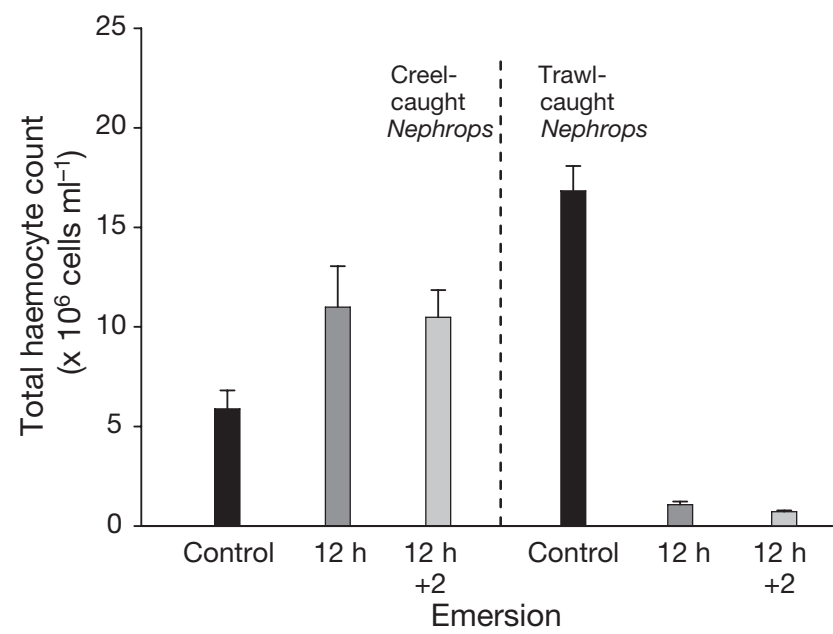

Fig. 2. Nephrops norvegicus. Haemolymph total haemocyte count (mean + SE) in creeled and trawled specimens after $0 \mathrm{~h}$ (control), $12 \mathrm{~h}$ emersion, and $12 \mathrm{~h}$ emersion and $2 \mathrm{~h}$ re-immersion $(\mathrm{n}=6)$ 


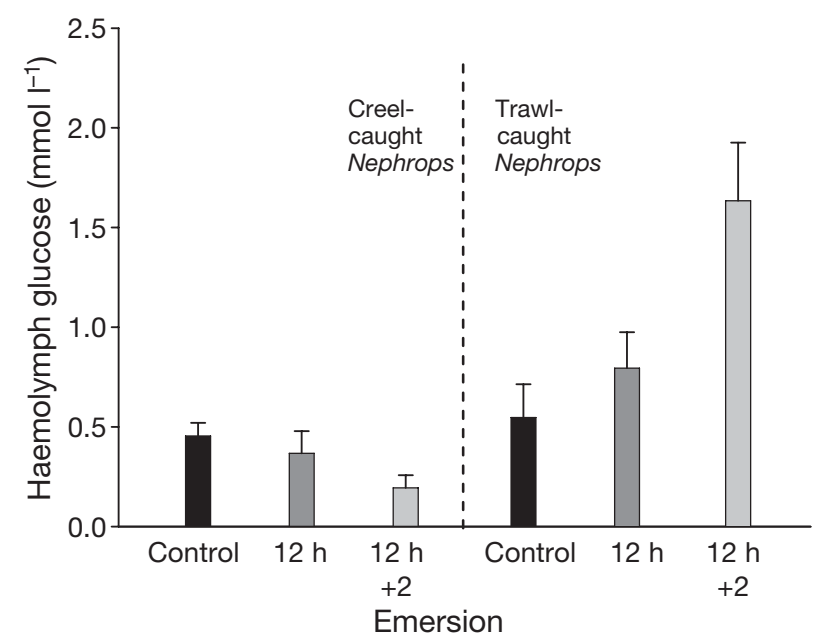

Fig. 3. Nephrops norvegicus. Haemolymph glucose concentrations (mean $+\mathrm{SE}$ ) in creeled and trawled specimens after $0 \mathrm{~h}$ (control), $12 \mathrm{~h}$ emersion, and $12 \mathrm{~h}$ emersion and $2 \mathrm{~h}$ re-immersion $(n=6)$

by haemocyte counts, ProPO activation, phagocytic indices, and release of free oxygen radicals.

The release of mature haemocytes from the haematopoetic tissue (HPT) is induced when haemocytes are degranulated in response to 'non-self' molecules, e.g. $\beta$-1,3-glucans and lipopolysaccharides (LPS) (Söderhäll et al. 2003). Degranulation capacity in Nephrops norvegicus decreased by $75 \%$ in the presence of $\mathrm{Mn}$ (Hernroth et al. 2004) and $\mathrm{Mn}$ is also suggested to inhibit the induction of proliferation of the stem cells. A compensatory proliferation is otherwise a normal reaction to decreased THC. Here, it appears that a decrease in degranulation occurred in trawled animals exposed to $12 \mathrm{~h}$ of emersion. This suggests that the animals are attempting to compensate for increased stress brought about by the capture method. In contrast, the number of circulating haemocytes in the creeled animals increased during the $12 \mathrm{~h}$ emersion period in the creeled lobsters but decreased during the same emersion period in trawled individuals.

A low circulating haemocyte number in crustaceans is strongly correlated with long clotting times (Sindermann 1971) and a greater sensitivity to pathogens (Persson et al. 1987, Le Moullac et al. 1998). Hence, an attrition-induced, low THC indicates a higher susceptibility to infectious diseases (Newman \& Feng 1982, Field \& Appleton 1995, Jussila et al. 1997, Lorenzon et al. 2001). The finding here of a significant THC decrease in trawled Nephrops norvegicus (cf. the increase in the creel-caught lobsters) suggests that trawling may impose irreversible stress. Smith et al. (1995) found that Crangon crangon exposed to dredge spoils showed an elevation in recoverable

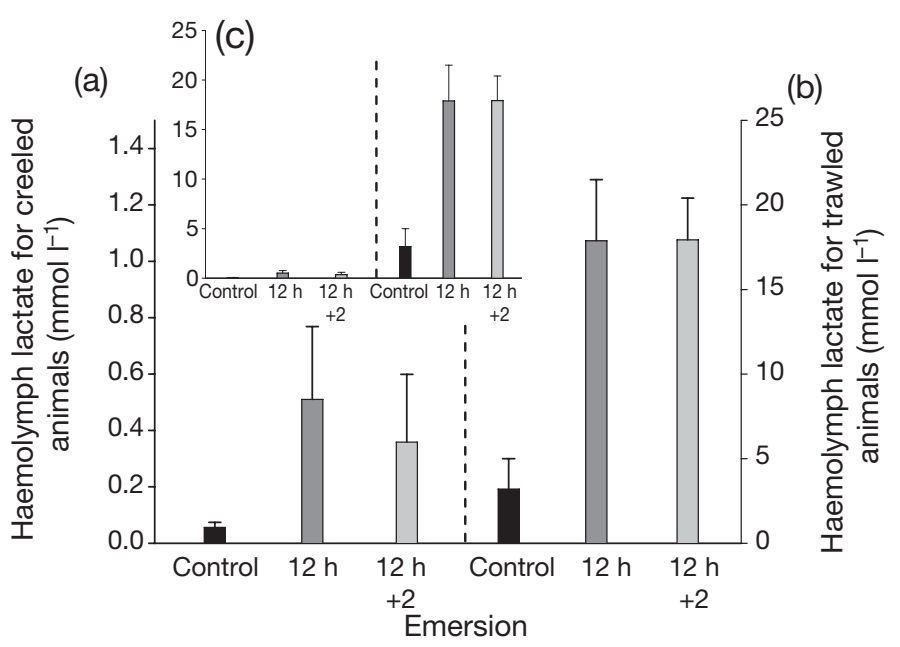

Fig. 4. Nephrops norvegicus. Haemolymph L-lactate concentrations (mean $+\mathrm{SE}$ ) in (a) creeled, and (b) trawled specimens after $0 \mathrm{~h}$ (control), $12 \mathrm{~h}$ emersion, and $12 \mathrm{~h}$ emersion and $2 \mathrm{~h}$ re-immersion. (c) Combined plot of creeled and trawled L-lactate concentrations $(n=6)$

haemolymph volume and a reduction in their $\mathrm{THC}_{\text {; }}$ thus, such environmental stresses may produce a similar response in other species.

In this study, THC and PO activity were always negatively related in the trawled Nephrops norvegicus after emersion and this contrasts with the increases in both parameters (cf. control lobsters) in the creeled lobsters. Lowered THC and increased PO activity that followed a $24 \mathrm{~h}$ exposure of Litopenaeus stylirostris to hypoxia was attributed to lower amounts of plasma serine proteinase inhibitors regulating the ProPO system (Le Moullac et al. 1998). Negative correlations between PO activity and THC have also been found in the shore crab Carcinus maenas (Hauton et al. 1995) and in the common shrimp Crangon crangon (Smith \& Johnston 1992).

A lowered THC may be a consequence of haemocyte immobilisation in the gills, as shown in mercuryexposed prawns (Victor et al. 1990), and is similar to the inflammatory reaction observed in Carcinus maenas after an infection (Smith \& Ratcliffe 1980). The 12 $\mathrm{h}$ emersion-induced THC increase in the trawled group and decrease in the creeled group $(\mathrm{p}<0.05$ in each case) suggests that a lowered haemocyte count may have little to do with altered gill function in Nephrops. Jussila et al. (1997) suggested that a THC $<4 \times 10^{6}$ cells ml $^{-1}$ was indicative of poor condition or health in lobsters. The trawled Nephrops norvegicus in this study had mean THC values of $1.1 \pm 0.20 \times$ $10^{6} \mathrm{cells} \mathrm{ml}^{-1}$ and $0.7 \pm 0.07 \times 10^{6}$ cell ml${ }^{-1}$ for the $12 \mathrm{~h}$-emersed and re-immersed groups, respectively, suggesting that their condition had deteriorated (cf. the creel-caught lobsters which maintained a THC 


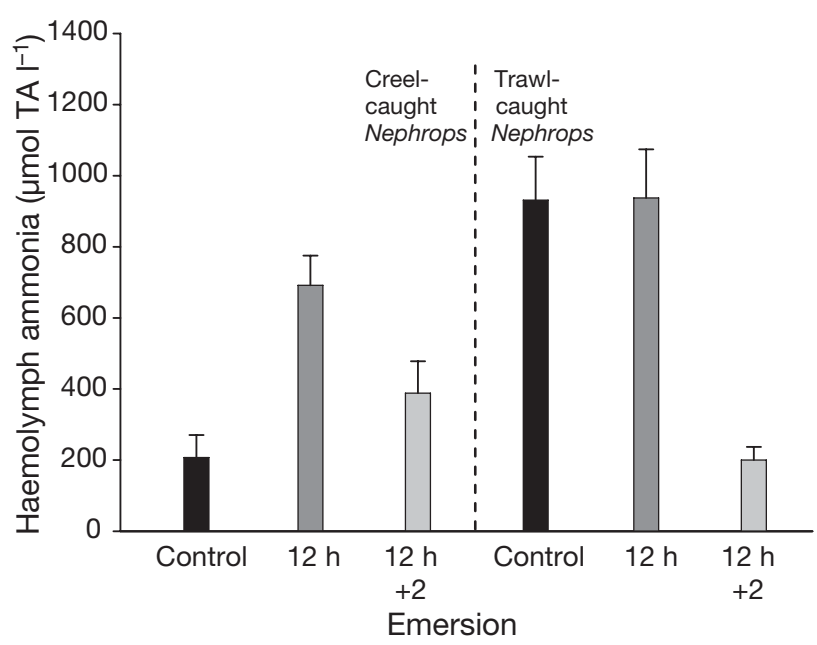

Fig. 5. Nephrops norvegicus. Haemolymph ammonia concentrations (mean $+\mathrm{SE}$ ) in creeled and trawled specimens after $0 \mathrm{~h}$ (control), $12 \mathrm{~h}$ emersion, and $12 \mathrm{~h}$ emersion and $2 \mathrm{~h}$ re-immersion $(\mathrm{n}=6)$. TA: total ammonia

which was probably more representative of the lobsters in the wild: $11.0 \pm 2.07 \times 10^{6}$ cells ml $^{-1}$ and $10.0 \pm$ $1.37 \times 10^{6} \mathrm{cells} \mathrm{ml}^{-1}$ ).

The initial haemolymph TA difference between the control groups probably reflects the different stress intensities imposed by the 2 capture methods. During trawling, animals not only have to endure the stress of being dragged behind the boat in a net for hours but, once hauled, the animals are released into a shoot and may be left there for up to an hour prior to being sorted by the fishermen.

Emersion-induced increases in haemolymph TA have been described for Cancer productus (DeFur \& McMahon 1984), C. pagurus (Regnault 1992), Nephrops norvegicus (Schmitt \& Uglow 1997), and Necora puber (Durand \& Regnault 1998). Here, despite the differences in capture method, most of the accumulated ammonia was excreted from both groups within $2 \mathrm{~h}$ of re-immersion.

Under severe hypoxia, it is important for active crustacean species that use normal glycolysis with L-lactate (lactic acid) as their anaerobic end-product, to minimise activity and retard the depletion of glycogen reserves (Hagerman 1998). The present findings suggest that the extent of glycogen reserve depletion when captured varies with the capture method used as substantiated by the significant difference in the L-lactate concentrations between the creeled and trawled groups $\left(0.06 \pm 0.02\right.$ and $3.20 \pm 1.80 \mathrm{mmol} \mathrm{l}^{-1}$, respectively). This difference widened with the continued lactate increase in the trawled group during the $12 \mathrm{~h}$ emersion period and, again, probably reflects the severity and duration of the stresses associated with trawling, which was observed to induce extensive tail- flipping escape behaviour when the nets were being emptied).

Experimental emersion induced a pronounced haemolymph hyperglycaemia in the trawled group and this persisted into the subsequent re-immersion. On the other hand, the creeled group which had significantly lower mean haemolymph glucose levels before emersion, became hypoglycaemic when emersed and their haemolymph glucose concentration continued to decrease during re-immersion. These findings further highlight the greater stress intensity that trawling (vs. creeling) has on Nephrops norvegicus and implies that trawling and emersion induce a more severe depletion of the glycogen reserves than creeling does.

\section{CONCLUSION}

This study has demonstrated that the capture method and subsequent emersion of Nephrops norvegicus result in stress responses that are manifested by changes in their physiology and immunology. As a benthic burrowing species, $N$. norvegicus can be and has been affected by eutrophication-induced prolonged periods of severe hypoxia and anoxia. Hagerman \& Baden (1988) indicate that the species is very hypoxia-tolerant, but this relates to relatively immobile individuals. The combined stresses of lengthy capture procedures, physical injury and emersion that occur when $N$. norvegicus is fished suggest that their emersion tolerance will be compromised unless positive steps are taken to avoid emersion (e.g. keeping lobsters immersed in good quality seawater whenever possible, especially soon after capture, while awaiting first sale, and certainly before packing and consigning). Large temperature variations should also be avoided (e.g. between ambient temperature at place of capture and at place of despatch) in existing protocols so that these better meet the needs of the animals. As $N$. norvegicus currently comprises the second most valuable UK fishery ( $7 \%$ of the 2005 landings but $18 \%$ of total value; DEFRA July 2006), and as customer requirement is increasingly for live, good quality product delivered to a distant point of sale, then pragmatic commercial (as well as humane) considerations indicate that protocol changes based on the physiological tolerances of the animals are needed to meet customer requirements.

Acknowledgements. Studies were partly funded by the Irish Fisheries Board. We thank Sutherland Fish and Game, Scotland for supplying the creel-caught specimens and Storrus Seafood of Whitby for supplying trawled specimens. This research was conducted in accordance with institutional, national and international guidelines on the use of animals in research. 


\section{LITERATURE CITED}

Bauchau AG (1981). Crustaceans. In: Rawcliffe NA, Rowley AF (eds) Invertebrate blood cells, Vol 2. Academic Press, Sydney, p 385-420

Cerenius L, Söderhall K (1995) Crustacean immunity and complement: a premature comparison? Am Zool 35:60-67

DEFRA (Department for Environment, Food and Rural Affairs) (2006) United Kingdom Sea Fisheries Statistics. Available at: www.mfa.gov.uk/statistics/documents/ UKSeaFishStats_2006.pdf (accessed July 2006)

DeFur PL, McMahon BR (1984) Physiological compensation to short-term air exposure in red rock crabs, Cancer productus Randall, from littoral and sublittoral habitats. I. Oxygen uptake and transport. Physiol Zool 57:137-150

> Durand F, Regnault M (1998) Nitrogen metabolism of two portunid crabs, Carcinus maenas and Necora puber, during prolonged air exposure and subsequent recovery: a comparative study. J Exp Biol 201:2515-2528

Field RH, Appleton PL (1995) A Hematodinium-like dinoflagellate infection of the Norway lobster Nephrops norvegicus: observations on pathology and progress of infection. Dis Aquat Org 22:115-128

Hagerman L (1998) Physiological flexibility: a necessity for life in anoxic and sulphidic habitats. Hydrobiologia 375-376:241-254

Hagerman L, Baden SP (1988) Nephrops norvegicus: field study of effects of oxygen deficiency on haemocyanin concentration. J Exp Mar Biol Ecol 116:135-142

Hauton C, Hawkins LE, Williams JA (1995) Circatidal rhythmicity in the activity of the phenoloxidase enzyme in the common shore crab Carcinus maenas. Comp Biochem Physiol 111B:347-352

Hernandez-Lopez J, Gollas-Galvin T, Vargas-Albores F (1996) Activation of the prophenoloxidase system of the brown shrimp (Penaeus Californiensis Holmes). Comp Biochem Physiol 113C:61-66

Hernroth B, Baden SP, Holm K, Andre T, Söderhäll I (2004) Manganese-induced immune suppression of the lobster Nephrops norvegicus. Aquat Toxicol 70:223-231

Hunter DA, Uglow RF (1993) Moult stage-dependent variability of haemolymph ammonia and total protein levels in Crangon crangon (L.) (Crustacea, Decapoda). Ophelia 37: $41-50$

> Jackson AD, Smith VJ, Peddie CM (1993) In vitro phenoloxidase activity in the blood of Ciona intestinalis and other ascidians. Dev Comp Immunol 17:97-108

> Jussila J, Jego J, Tsvetnenko E, Dunstan B, Evans LH (1997) Total and differential haemocyte counts in western rock lobsters (Panulirus cygnus George) under post-harvest stress. Mar Freshw Res 48:863-867

> Le Moullac G, Soyez C, Sauliner D, Ansquer D, Avarre JC, Levy P (1998) Effect of hypoxic stress on the immune response and resistance to vibriosis of the shrimp Penaeus stylirostris. Fish Shellfish Immunol 8:621-629

Lorenzon S, Francese M, Smith VJ, Ferrero EA (2001) Heavy metals affect the circulating haemocyte number in the shrimp Palaemon elegans. Fish Shellfish Immunol 11: 459-472

Newman MC, Feng SY (1982) Susceptibility and resistance of

Initial editorial responsibility: Anne Berit Skivtesvik, Storebø, Norway; Final editorial responsibility: John Austin, Oldendorf/Luhe, Germany the rock crab Cancer irroratus to natural and experimental bacterial infection. J Invertebr Pathol 40:75-88

Perazzolo LM, Barracco M (1997) The prophenoloxidase activating system of the shrimp Penaeus paulensis and associated factors. Dev Comp Immunol 21:385-395

Persson M, Vey A, Söderhäll K (1987) Encapsulation of foreign particles in vitro by separated blood cells from crayfish, Astacus leptodactylus. Cell Tissue Res 247: 409-415

Regnault M (1992) Effect of aerial exposure on nitrogen metabolism in the crab Cancer pagurus. J Exp Zool 264: 372-380

Schmitt ASC, Uglow RF (1997) Haemolymph constituent levels and ammonia efflux rates of Nephrops norvegicus during emersion. Mar Biol 127:403-410

Sindermann CJ (1971) Internal defenses of Crustacea: a review. Fish Bull (Wash DC) 69:455-489

Smith VJ, Johnstone PA (1992) Differential haemotoxic effect of PCB congeners in the common shrimp Crangon crangon. Comp Biochem Physiol 101C:641-649

Smith VJ, Söderhall K (1983) $\beta$-1,3-glucan activation of crustacean haemocytes in vivo and in vitro. Biol Bull 164: 299-314

Smith VJ, Ratcliffe NA (1980) Host defense reactions of the shore crab, Carcinus maenas (L.): clearance and distribution of injected test particles. J Mar Biol Assoc UK 60:89-102

Smith VJ, Swindlehurst RJ, Johnston PA, Vethaak AD (1995) Disturbance of host defence capability in the common shrimp, Crangon crangon, by exposure to harbour dredge spoils. Aquat Toxicol 32:43-58

Söderhäll K (1981) Fungal cell wall $\beta$-1,3-glucans induce clotting and phenoloxidase attachment to foreign surfaces of crayfish haemocyte lysate. Dev Comp Immunol 5:565-573

Söderhäll K (1982) Prophenoloxidase activating system and melanization: a recognition mechanism of arthropods? A review. Dev Comp Immunol 6:601-611

Söderhäll K, Cerenius L (1998) Role of the prophenoloxidaseactivating system in invertebrate immunity. Curr Opin Immunol 10:23-28

Söderhäll K, Smith VJ (1983) Separation of the haemocyte populations of Carcinus maenas and other marine decapods, and prophenoloxidase distribution. Dev Comp Immunol 7:229-239

Söderhäll I, Bangyeekhun E, Mayo S, Söderhäll K (2003) Hemocyte production and maturation in an invertebrate animal: proliferation and gene expression in hematopoietic stem cells of Pacifastacus leniusculus. Dev Comp Immunol 27:661-672

Uglow RF, Hosie DA, Johnson IT, MacMullen PH (1986). Live handling and transport of crustacean shellfish: an investigation of mortalities. Technical report 280. Sea Fish Industry Authority, Edinburgh

Victor B, Narayanan M, Nelson DJ (1990) Gill pathology and hemocyte response in mercury exposed Macrobrachium idae (Heller). J Environ Biol 11:61-65

Yildiz HY, Atar HH (2002) Haemocyte classification and differential counts in the freshwater crab, Potamon fluviatilis. Turk J Vet Anim Sci 26:403-406

Submitted: November 28, 2006; Accepted: June 24, 2008

Proofs received from author(s): August 20, 2008 